\title{
TECHNOPARK BASED ON HIGHER EDUCATIONAL INSTITUTIONS OF RUSSIA
}

\author{
Romanovich L.G. \\ Belgorod state technological University named after \\ V. G. Shukhov \\ Belgorod, Russia \\ bel31rm@yandex.ru \\ Romanovich M.A. \\ Belgorod state technological University named after \\ V. G. Shukhov \\ Belgorod, Russia
}

\author{
Yarmolenko I.V. \\ Belgorod state technological University named after \\ V. G. Shukhov \\ Belgorod, Russia \\ Kuznetsova I.A. \\ Belgorod state technological University named after \\ V. G. Shukhov \\ Belgorod, Russia
}

\begin{abstract}
Technoparks are an effective instrument for stimulating the innovative activity of universities and have a significant influence on the socio-economic development of the regions. In the article the authors studied the problems of creating technoparks on the basis of higher educational institutions of Russia and gave recommendations in this field.
\end{abstract}

Keywords - technopark, innovative activity of universities, innovative infrastructure, innovative system.

\section{INTRODUCTION}

The problems of creating technoparks have attracted increasing attention of scientists, scientific centers and state bodies at all levels. Various measures are being taken to replicate the successful international experience of wellknown technoparks, created, as a rule, at large scientific centers. Technoparks are designed to stimulate the development of new companies involved in high technology and high-tech business. At the same time, particular in Russia, there is an urgent problem of organizing efficient technoparks due to differences and peculiarities: historical, regional, socioeconomic, regulatory, financial, and other. The results of our research have shown that in the Russian Federation the activity of technoparks is not highly efficient. They do not have a significant influence on the economic and innovative development of the country and its regions. Overcoming the low efficiency of domestic technoparks will mean the achievement of global competitiveness by the Russian economy [1]. At the same time, we have accumulated positive international experience of successfully operating technoparks on the basis of universities. It is taken into account when developing the authors' recommendations and can be used in normative and programmatic documents for the development of technoparks in various regions of Russia and foreign countries.

\section{THE BASIC PART}

At present, such an element of the structure of the national innovation system (NIS), as a technopark is widespread in developed countries, and the level of innovation activity is determined precisely by this element. Technopark structures are present in all countries with developed NIS. Such countries are the USA, Great Britain, France, Germany, China, Japan, Canada, Australia, etc., where all elements of the national innovation system are concentrated.

Economically developed countries assess the advantages of innovative business and prospects for the development of their economies, build up its formation and development systems, invest in innovative business investment. Innovative business is a way of achieving priorities in the fields of science, technology and economics; because its main task is not just profit, but profit from the introduction of new developments. Therefore, for many countries, the need for the transition of national economic systems to an innovative development path is evident. And the government chooses an innovative way of development and cannot do without the main guides of new technologies and innovations, which are small innovative enterprises (SIE).

Particularly important for innovative development are partnerships between the three leading institutional sectors the state, business and science / universities, called the Triple Helix Model. This concept entered the economic life in the mid-1990s and was designed to help developed countries become the basis of innovation policy for the transition they started from the knowledge economy. Technoparks were an infrastructural element that facilitated such a transition. And the most effective form of stimulating economic development, the integration of science and production in developed countries are structures of the technopark type.

The beginning of technoparks was initiated in the US in the early 50s, when Stanford University began to attract laboratory and vacant premises, separate research teams, small 
firms engaged in high-tech business, mainly performing military orders of the Ministry of Defense. The cooperation of small manufacturing companies with university scientists was the first successful experience in the development of a knowledge-based, and, as it turned out, profitable business, which gradually grew into a small one and turned into a large, independent one. Becoming independent, it, nevertheless, did not lose its ties with the university, which benefited both business, the university and the economy of the region. This is how the regional specialized technoparks appeared in the United States, then various "silicon valleys", and later - special economic zones that became the basis for copying innovative business around the world [1].

In Russia, the formation of technoparks began in the early 1990s, mainly in higher education. The first was the Tomsk Science and Technology Park, which opened on the basis of Tomsk State University of Control Systems and Radioelectronics. Since then, the number of industrial parks gradually increased and by 1992 there were already 24 of them in Russia. Later, technoparks began to appear on the basis of state scientific centers, in academic towns, science cities and by the year 2000 there were 54 of them [2.3].

They, in the majority, were created as structural divisions of high schools, whose collectives understood the necessity of development of cooperation of science and production. They did not supported by financial security, which the university did not have the right to carry out to commercial organizations. Nevertheless, they became the first experience of commercialization of scientific developments..

Since 2006, federal specialized programs have been developed in Russia and funds allocated for the development and creation of technoparks. One such program was a comprehensive program coordinated by the Ministry of Communications and Mass Communications of the Russian Federation "Establishment of technology parks in the Russian Federation in the sphere of high technologies", which was completed in 2014. 13.4 billion rubles was allocated to realize it for eight years from the federal budget. According to another program coordinated by the Ministry of Education and Science of Russia since 2009, about 9 billion rubles have been allocated to create three dozen industrial parks. Another four technoparks have appeared since 2010 through the Ministry of Economic Development of the Russian Federation. Given there is this trend, many regions of the Russian Federation also found it necessary to initiate such technopark sites on an initiative basis. Thus, by 2013 more than 200 technoparks have been formed in the country (Fig. 1) [4].

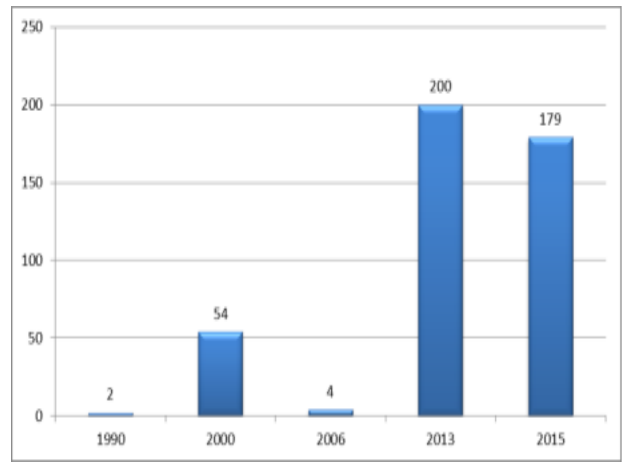

Fig. 1. Dynamics of the organization of technoparks in Russia from 1990 to 2015

But, in spite of a significant number, we should note, in our opinion, the following significant problems in this area:

1. Lack of a clear definition of what should be considered a technopark and what goals it should pursue.

2. Lack of the legislative base that would define goals, objectives, evaluation criteria, principles of functioning and the role of technology parks in the national innovation system.

3. Absence in the programs of clear requirements for the infrastructure and technical equipment of technoparks.

4. Large interdepartmental disunity in the creation of the Russian innovation infrastructure.

5. Lack of financial levers and sources for the formation and development of SIE in universities, often without other means to implement innovative projects, in addition to the personal investment of individuals, investment of the organizers themselves and founders of small innovative enterprises.

6. The lack of interest of the business sector in financing innovative projects, the inability to realize these projects by small grants of funds and state structures put the created SIE often on the brink of survival.

In the current economy, the following types of technoparks can be distinguished: university parks, regional industrial parks, industrial parks, industrial technology parks, technoparks based on science cities.

As a result of the analysis of economic literature $[5,6,7,8]$, it is found that at present only $2 \%$ of technoparks, which are more than ten years old, operate in Russia. The remaining $98 \%$ are actually at the stage of creation or development. At the same time, only a few of the currently functioning infrastructures (high-tech equipment, laboratories, etc.) are functioning, and the providing of services necessary for resident companies (business acceleration, mentoring, assistance in attracting investments, etc.) claims hardly $10 \%$ of the currently functioning technoparks.

Russia is one of the world leaders in the quality of labor resources: even when taking into account the numerous problems of the Russian education system, the Russians remain one of the most educated nations. In addition, in terms of funding science, our country ranks 8th in the world. But, 
unfortunately, a good educational base and strong science do not give us practical results, which is a structural problem of the development of the national innovation sector of the economy. The scientific community in Russia exists separately from business. In turn, businessmen are not riskaverse, do not hurry to invest in science-intensive projects and give preference to ready technological solutions of foreign origin. If we compare Russia and the USA, then the United States in the world accounts for $21 \%$ of the innovation market, and the share of Russian producers - only $1 \%$.

In modern conditions, long-term projects in Russia frighten entrepreneurs away, despite the fact that in the long term they can receive significant returns. However, most business representatives prefer to receive small but stable profits in the short term. This tactic across the country leads to technological lagging, and in the end - to a decrease in competitiveness. The structure of Russian technoparks in the area of their specialization is dominated by multi-sectoral technology parks (31\%) and information technology (29\%). The minimum activity of industrial parks in Russia falls to the sphere of agriculture. The whole structure of technoparks is shown in Figure 2.

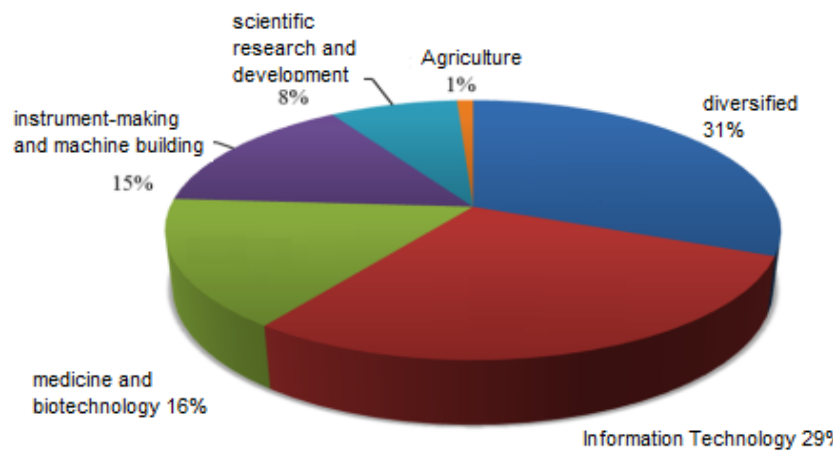

Fig. 2. Specialization of Russian technoparks

Ownership of Russian technology parks determines the level of financing they provide, and, consequently, the potential for implementation of projects. In the structure of ownership, technoparks, presented in Fig. 3, are dominated by regional administrations, which account for $39 \%$ of the gross volume of creation and support of technoparks. In the second place, there is the administration of universities, which was formed and supported by $26 \%$ of Russian technoparks. The minimum number of them falls to municipal administrations (13\% of technoparks).

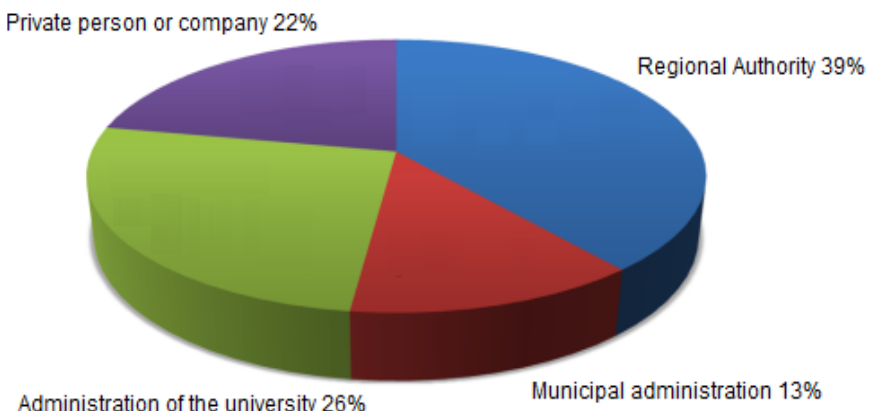

Fig. 3. The owners of Russian technoparks

The reality is the separation of activities for the formation of the material infrastructure of technoparks from the activities for the development of innovative (service) infrastructure are observed not only by "public men". The fact that these areas are not linked to a coherent and harmonious system is also said by the auditors of the Accounts Chamber of the Russian Federation, which revealed numerous violations in the creation of technoparks within the framework of the comprehensive program of the Ministry of Communications and Mass Media of Russia. It turned out that between of 12 technoparks participating in the program and located in 11 regions of the Russian Federation, only five were built entirely in three regions (three in Tatarstan, one in Kemerovo and Tyumen regions). Three more technoparks - in Moscow, Sverdlovsk and Kaluga regions - at the time of the inspection no resident company was located at all. And still there were no significant results for such indicators as the number of completed experimental and research and research works, the number of patents received for inventions [6].

Technoparks in their idea, as they were conceived about half a century ago, and by the way they are developing at the fastest pace in the USA (where the technoparks are the most about 150) are not what we do. In contrast to our practice, where techno parks are another faculty of the university or laboratory of the plant, designed only to promote the implementation of the development of its specialists, in the West they have considerable freedom from the founders. European and American technoparks are guided by the same principles as any independent commercial firm - economic efficiency [9] and choose customers accordingly. If the Russian practice does not go beyond its current narrow framework of structures that only serve for the needs of the founders, then our prospects in this sense are rather modest [10].

It can be seen in the dynamics of the development of domestic technoparks - it is much inferior to the western rates. In Finland, for example, there are already 7 technoparks, somewhat different from each other, but similar in the main they are independent in their work. The largest is the technopark in Tampere. There is no such thing in Russia and is not expected in the near future. Although by age, it is comparable with ours, but by power and perspective far surpasses the latter. Even in the face of the severe economic crisis that now has its place in Finland, it can be attributed to a small number of well-off enterprises. The secret of success is in independence from the "fathers" [11]. The Technopark in 
Tampere was established by the University and the Science and Technology Center. At the initial stage it used all the benefits provided by the state for universities. But in its work the technopark in Tampere is completely independent as all other most prosperous western technoparks. Being a powerful independent structure, it directly (and not through founders, as we do) is connected with investors, banks and industrial enterprises.

In St. Petersburg, there are several technoparks organized at large universities. This origin is normal and natural. The bad news is that they do not have their own legal personality; they do not have the right to invite people from the street as clients. Even in the best technoparks, such as the technopark of the Electrotechnical University, all the clients are professors, associate professors, graduates of the same university, which try to help them to realize their wonderful ideas through the technopark. This sets limits of the technopark in a maneuver, greatly restrains its development. If this could still be understood in the first year or two, at an early stage, then in the long term such policy seems to be erroneous. The administration of technoparks should be able to choose a client, based on the project of its business plan. According to forecasts, if our technoparks do not get out of their current semi-embryonic state, at the end of the state program for supporting technoparks, they are most likely to die [12].

The initiators of innovative business on the basis of higher education institutions are increasingly beginning to understand that a positive result can be achieved only by interacting with each other, which makes them think about the organization of technology parks at universities as one of the most effective mechanisms for the infrastructural support of small business [13].

In addition, the experience of the autonomous existence of small innovative enterprises on the basis of author's scientific teams shows that the most effective form of organizing SIE can be their creation on the basis of existing small business enterprises. In this case, starting capital, the accumulated experience of financial management and an organized production base may appear $[14,15]$.

Thus, the association in SIE of participants from the sphere of science and small business is the most real way for the normal functioning and development of these enterprises, and with the financial support of the state at the stage of formation, this will help ensure their effective innovative development. The merger of intellectual, financial and technological resources of SIE, their unification into a single managing enterprise - technopark, according to the authors, will be a condition for the normal development of innovative business in universities. University technological, scientific and research parks are designed to stimulate the process of creating start-up companies engaged in the development of research and technology on the basis of universities, as well as the process of commercialization of intellectual property results.

\section{CONCLUSION}

1. The results of the analysis showed that the development of technopark in Russia is an important element in the formation of the stability of the economic system of the Russian Federation.

2. At present, attempts are being made to support science and education. However, a systematically worked out integrated state scientific and technical policy covering science, technology, education, introduction and scientific and technological modernization of production has not yet been fully formed on the Russian scale.

3. Systemic study of the state scientific and technical policy should encompass the support and stimulation of science, domestic high and knowledge-intensive technologies, transfer technologies, the expansion of scientific and technical personnel potential, informatization policy, the development of scientific elites, support for the status of science and scientists, the concept of the science budget, various forms of financing, social problems: prestige, social guarantees, the status of scientists, relations with society, the foundations of regional scientific and technological policy, the creation of new organizational forms and interaction with production, new forms - technopolises, techno-cities, technology parks, incubators and other.

4. Technoparks are an important element of the modern economy. Technoparks can be viewed from several points of view:

Firstly, the technopark can be regarded as a special type of free economic zone, in the territory of which the development of science-intensive products is intensively developing, new personnel, technical and innovative zones are being formed, on this side the technopark meets the requirements for compliance with the main processes occurring in the world economy.

Secondly, science provides an incentive for the development of business, mainly small, which allows us to talk about technoparks as a form of support for small business, the development of which allows us to reach a qualitatively new stage of social reproduction.

Thirdly, in such parks, science receives financial and other additional opportunities for conducting fundamental and applied research, thereby making science more independent from the state. In this regard, technoparks are an attractive form of support for domestic science.

5. Taking into account the fact that the most important strategic goal of Russia is the transfer of the economy to an innovative type of development, and one of the forms of activation of innovative activity and state support for entrepreneurship is the effective functioning of technoparks. The primary task of the legislator is the need to adopt a federal law "On Technoparks in the Russian Federation", in which there is a concept of the technopark, the purpose of its creation, the peculiarities of the legal regime of its functioning, effective measures of state support of technoparks and their subjects. This will contribute to the development of science-intensive technologies and science-intensive firms, the 
successful commercialization of innovative developments of domestic universities and the development of competitive entrepreneurship.

Thus, the process of building and development of technoparks should not bypass Russia in the conditions of the global world economic crisis. One of the ways out of the current crisis is to rely on domestic science and scienceintensive production. In connection with this, technoparks can play one of the most important roles in this process.

\section{Acknowledgement}

The work has been carried out in the framework of the program of development of the flagship university on the basis of BSTU named after V.G. Shukhov.

\section{References}

[1] E.M. Khaikina, Yu.S. Sizova "Development of Technoparks in the Russian Federation” Young Scientist, 2016, № 14, p. 409-412.

[2] R.I. Akmaeva "Innovative management of a small enterprise operating in the scientific and technical sphere", Rostov n/a, Phoenix, 2012, p. 541.

[3] N.L. Marenkov, M.A. Zolotareva "Innovations in Russia: Textbook. Allowance". Moscow: Flint: IPSI, 2005.

[4] A. V. Vilensky "Paradox of support of small business: preliminary results of crisis", Issues of economy, 2011, № 6, p. 152-153.

[5] N. Alekseeva "Why invest in Russian technology parks?" The sociopolitical journal, Public Russia, 2014.

[6] A. Moskalenko “Technobus” Business Journal, 2016, № 1, p. 38-43.

[7] Yu.S. Sizova "Development of Technopark Structures in the Moscow Region: Dynamics, Factors, Prospects" Economics and Entrepreneurship, 2016, No. 3-1 (68-1), p. 270-272.
[8] L.G. Romanovich, E.I. Evtushenko, M.A. Romanovich, D.V. Kudinov "Innovation activity and business incubators based on institutio of higher education. the experience of Russia" journal of applied engineering science, 2015, v. 13. № 3, p. 161-166.

[9] Charles W. Wessner "Understanding Research, Science, and Technology Parks: Global Best Practices, Report of a Symposium I Committee on the Comparative Innovation Policy: Best Practice for the 21st Century, the Board on Science, Technology, and Economic Policy, Policy and Global Affairs, National Research Council”, Washington, D.C .: National Academies Press, 2009. p. 7.

[10] L. Romanovich, V. Sevostyanov, M. Romanovich, M. Sevostyanov, A.Y. Arkatov "Innovation activity and technology transfer of higher education” Journal of Applied Engineering Science, 2014, v. 12. № 4, p. 273-276.

[11] "University Entrepreneurship and Technology Transfer: Process Design and Intellectual Property” Elsevier, 2005, p. 14-57.

[12] L.G. Romanovich, M.A. Romanovich, V.V. Vybornova, V.N. Riapukhina "SMALL BUSINESSES IS A SPHERE OF INNOVATION IN THE AGE OF GLOBALIZATION” Journal of Applied Engineering Science, 2014, v. 12. № 4, p. 297-301.

[13] V. Vybornova, S. Vybornova, L. Romanovich, M. Romanovich "THE COST REDUCTION - THE MAIN CONDITION FOR SUSTAINABLE DEVELOPMENT OF INDUSTRIAL ENTERPRISES” Journal of Applied Engineering Science, 2015, v. 12. № 4, p. 261.

[14] A.N. SKIBA "System effect of state, market and science interaction in conditions of technopark structures" Regions. Economics: theory and practice, 2010, No. 3, p. $16-22$.

[15] D.R. Fedorova, V.C. Tarverdiev "Features of functioning of technopark structures at the present stage of the transition economy" The Sixth International Scientific Congress "The Role of Business in the Transformation of Russian Society - 2011" (April 18 - 22, 2011), M., 2011, p. 191 - 194. 